\title{
KEPEMIMPINAN DAN MANAJEMEN KEPALA MADRASAH (STUDI KASUS KEPALA MTSN SUNGAYANG BERPRESTASI TINGKAT NASIONAL)
}

\author{
Sastra Deni R \\ Madrasah Ibtidaiyyah Negeri Sungai Tarab, Batusangkar, Sumatera Barat, Indonesia \\ e-mail: sastradenir7171@yahoo.com
}

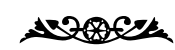

\begin{abstract}
This research is aimed at describing the leadership of the Head Master of MTsN Sungayang in achieving a better quality school. The research applied a qualitative paradigm. The techniques of data collection of this study were interviews, observation and documentary study. The technique of data analysis applied the interactive model by Miles and Huberman. For checking data trustwohiness, triangulation technique was applie, namely by comparing the results of observation data with those of interview, and documentation. The findings of the study show that the school principal plans the programs, performing short speeches (muhadaroh) in the Madrasah, providing religious vocabulary, habituating the students to perform Dhuha prayer and noon prayer together, evaluating classrooms cleanliness, making Madrasah wall magazine, creating Madrasah Health Unit (UKS), performing activities of Sports and Arts, of social like takziyah, visiting the sick people, and collecting money for social funds.
\end{abstract}

Keywords: kepemimpinan, manajemen, kepala sekolah

\section{PENDAHULUAN}

Dalam penyelenggaraan pendidikan di Madrasah, peran guru, kepala dan pengawas sangat penting dan strategis. Tugas dan tanggung jawab mereka sebagai pendidik, pemimpin, motivator dan supervisor serta mitra kerja sangat menentukan, dan oleh karena itu diperlukan adanya pembinaan yang efektif dan berkelanjutan. Selain itu, bagi mereka yang memiliki komitmen tinggi, kinerja yang bagus dan prestasi yang tinggi, selayaknyalah memperoleh pengakuan dan apresiasi dari semua pihak terkait, penting agar semangat kerja, kreativitas, dedikasi dan komitmen serta kinerja mereka dapat terus terpelihara dan meningkat dari waktu ke waktu.

Menurut N.A Amentembun dalam bukunya mengatakan dalam dunia pendidikan kepala madrasah juga menjadi motivasi dengan jalan memberi reward. Pemimpin di lembaga pendidikan Islam disebut dengan kepala madrasah, ia merupakan pemimpin pendidikan yang menempati posisi terdepan dan strategis dalam mengatur jalannya proses 
pembelajaran, administrasi dan hubungan antara sumber daya manusia, baik antara sesama guru, staf (karyawan) dan masyarakat lingkungannya serta antara Madrasah dengan wali murid. Pandangan ini sesuai dengan pendapat yang dikemukakan oleh Amentembun bahwa kepala madrasah menempati posisi terdepan dalam arena belajar mengajar yang dipimpinnya dan secara fungsional ia adalah puncak tanggung jawab atas proses pembelajaran yang berlangsung. (N.A Amentembun: 1982)

Menurut Direktorat Jenderal Pembinaan Kelembagaan Agama Islam Departemen Agama RI sebagai seorang lieder, tugas dan tanggung jawab yang harus dilaksanakan oleh kepala madrasah sangatlah berat. Oleh kerena itu, terdapat berbagai kemampuan yang harus dimiliki oleh kepala madrasah sebagai lieder, di antaranya:

1. Kemampuan mengorganisasi dan membantu staf dalam merumuskan perbaikan pengajaran di madrasah dalam bentuk program yang lengkap.

2. Kemampuan untuk membangkitkan rasa percaya diri guru-guru dan anggota stafnya.

3. Kemampuan untuk membina dan memupuk kerjasama dalam memajukan dan melaksanakan program-program supervisi.

4. Kemampuan untuk mendorong dan membimbing guru serta anggota staf lainnya agar mereka dengan penuh kerelaan dan tanggung jawab berpartisipasi secara aktif pada setiap usaha madrasah untuk mencapai tujuan.(Direktorat Jenderal Pembinaan Kelembagaan Agama Islam Departemen Agama RI, Manajemen Madrasah Aliyah, (Depag RI, 1999).

Sebagai implikasi Undang-undang Nomor 20 Tahun 2003 tentang Sistem Pendidikan Nasional, Pasal 40 Ayat (2) menyatakan bahwa pendidik, dan tenaga kependidikan berkewajiban memberi teladan dan menjaga nama baik lembaga, profesi dan kedudukan dengan kepercayaan yang diberikan kepadanya. Demikian juga Pemerintah memberikan perhatian yang serius untuk memberdayakan Guru, terutama bagi mereka yang berprestasi. Undang-undang Nomor 14 Tahun 2005 tentang Guru dan Dosen, Pasal 36 Ayat (1) mengamanatkan bahwa "Guru Yang Berprestasi, Berdedikasi Luar Biasa, dan atau bertugas di daerah khusus berhak memperoleh penghargaan. Sejalan dengan era globalisasi menuntut SDM yang bermutu tinggi dan siap berkopetisi baik di tataran nasional, regional maupun internasional. Untuk menghasilkan SDM bermutu dibutuhkan proses bermutu dari lembaga yang bermutu pula. (UU No 20/2003 dan UU No14/20105)

Untuk memacu dan memicu munculnya kepala madrasah berprestasi, serta guru berdedikasi perlu adanya kegiatan sistematis yang dapat menggali mereka yang berprestasi. Kegiatan sistematis yang dimaksud adalah pemilihan guru, kepala 
madrasah dan pengawas madrasah yang berprestasi serta berdedikasi. Program ini merupakan wujud perhatian pemerintah atas dedikasi dan prestasi serta guru berdedikasi dan diharapkan dapat memberikan dampak yang positif bagi masyarakat, pendidikan terhadap Kepala Madrasah.

Seorang pemimpin mempunyai tanggung jawab yang berat. Mengingat perannya yang sangat besar, keuletannya serta kewibawaannya dalam membuat langkah-langkah baru sebagai jawaban dari kebutuhan masyarakat. Hal ini sebagaimana ditulis oleh Bernard Kutner yang dikutip oleh Evendy M. Siregar tentang kepemimpinan:

"Dalam kepemimpinan tidak ada asas yang universal, yang nampak ialah proses kepemimpinan dan pola bubungan antar pemimpinnya. Fungsi utama kepemimpinan terletak dalam jenis khusus dari perwakilan (group representation). Seorang pemimpin harus mewakili kelompoknya sendiri. Mewakili kelompoknya mengandung arti bahwasi pemimpin mewakili fungsi administrasi secara eksekutif. Ini meliputi koordinasi dan integrasi berbagai aktivitas, kristalisasi kebijaksanaan kelompok dan penilaian terhadap macam peristiwa yang baru terjadi dan membawakan fungsi kelompok. Selain itu seorang pemimpin juga merupakan perantara dari orang dalam kelompoknya di luar kelompoknya." (Evendy M. Siregar: 1989)

Kepala sekolah sebagai manajer dapat menciptakan proses pendidikan yang bermutu apabila melakukan pengkoordinasian, penyerasian, dan pemanduan masukan yang dimilki sekolah secara harmonis sehingga akan memberikan dampak pada situasi pembelajaran yang menyenangkan. Dengan demikian input sekolah yang melibatkan sumber daya manusia seperti kepemimpinan sekolah, guru, siswa, dan masyarakat lingkungan sekitar serta sumber daya lainnya seperti sarana dapat berfungsi dengan tepat. Proses yang berjalan dengan harmonis ini akan mendorong motivasi dan minat belajar siswa sehingga menghasilkan lulusan yang berkualitas.

\section{LANDASAN TEORITIK}

Menurut Aan Komariah, dalam bukunya Cepi Triatna, Visionary Leadership mengatakan bahwa "Kepemimpinan adalah hal penting dalam organisasi. Suatu organisasi memiliki kompleksitas, baik barang/ jasa maupun ide, menghadapi berbagai perubahan yang senantiasa melingkupi setiap saat, menghadapi berbagai karakteristik personel yang dapat mengembangkan maupun melemahkan. Hal ini menjadi alasan diperlukannya orang yang tampil mengatur, memberi pengaruh, menata, mendamaikan, memberi penyejuk, dan dapat menetapkan tujuan yang tepat saat anggota tersesat atau kebingungan menetapkan arah. Disinilah perlunya pemimpin yang melaksanakan kepemimpinan”. (Aan Komariah: 2006)

Hendiyat Soetopo, mengatakan bahwa "Pengertian umum kepemimpinan adalah 
kemampuan dan kesiapan yang dimiliki seseorang untuk dapat mempengaruhi, mendorong, mengajak, menuntun, menggerakkan dan kalau perlu memaksa orang lain agar ia menerima pengaruh itu selanjutnya berbuat sesuatu yang dapat membantu pencapaian suatu maksud atau tujuan tertentu. (Hendiyat Soetopo: 1988)

Menurut pandangan Amitai Etzioni dalam Ngalim Purwanto, kepemimpinan adalah kekuatan (power) yang didasarkan atas tabiat/watak seseorang yang memiliki kekuasaan lebih, biasanya bersifat normatif. Pengertian kepemimpinan juga diungkapkan oleh Siagian, yang menyebutkan bahwa kepemimpinan adalah motor atau daya penggerak daripada sumber-sumber dan alat-alat (resources) yang tersedia bagi suatu organisasi. (M. Ngalim Purwanto: 1991)

Kepemimpinan dapat ditelaah dari berbagai segi tergantung dari konsep gaya kepemimpinan yang menjadi dasar sudut pandang. Karena beragamnya gaya kepemimpinan, melahirkan berbagai pendekatan atau teori kepemimpinan yang beragam pula. Sehingga efektifitas kepemimpinan dapat diidentifikasikan dari berbagai kriteria sesuai dengan konsep gaya kepemimpinan yang dipergunakan.

Keberhasilan kepala madrasah dipengaruhi oleh gaya kepemimpinannya terhadap bawahan (guru). Menurut Hersey dan Blanchard ".... the style of leaders is the consistent behavior patterns that they use when they are working with and through other people as perceived by those people", yang artinya bahwa gaya kepemimpinan adalah pola perilaku konsisten para pemimpin yang mereka gunakan ketika mereka bekerja dengan dan melalui orang lain seperti yang dipersepsi oleh orang-orang itu. (Paul Hersey, Blanchard and H. Kenneth: 1977)

Pada saat suatu proses kepemimpinan berlangsung, seorang pemimpin mengaplikasikan suatu gaya kepemimpinan tertentu. Gaya kepemimpinan yang efektif merupakan gaya kepemimpinan yang dapat mempengaruhi, mendorong, mengarahkan dan menggerakkan orang-orang yang dipimpin sesuai dengan situasi dan kondisi supaya mereka mau bekerja dengan penuh semangat dalam mencapai tujuan organisasi.

Hersey dan Blanchard menjelaskan bahwa gaya kepala sekolah yang efektif ada empat: (1) gaya instruktif, penerapannya pada bawahan (guru) yang masih baru atau bertugas. (2) gaya konsultatif, penerapannya pada bawahan (guru) yang memiliki kemampuan tinggi namun kemauan rendah, (3) gaya partisipatif, penerapannya pada bawahan (guru) yang memiliki kemampuan rendah, namun memiliki kemauan kerja tinggi, (4) gaya delegatif, penerapannya bagi bawahan (guru) yang memiliki kemampuan tinggi dan kemauan tinggi. (Paul Hersey, Blanchard and H. Kenneth: 1982)

Kata manajemen berasal dari bahasa latin, yaitu kata manus dan agree yang berarti malakukan. Kata-kata itu digabung menjadi kata kerja managere yang artinya 
menangani. Managere diterjemahkan dalam bahasa Inggris dalam bentuk kata kerja to manage, dengan kata benda dengan management, dan manager untuk orang yang melakukan kegiatan Manajemen. Akhirnya Manajemen diterjemahkan dalam bahasa Indonesia menjadi manajemen atau pengelolaan. (Husaini Usman: 2006)

Menurut Drs. Malayu S.P Hasibuan, mendefinisikan manajemen adalah ilmu dan seni yang mengatur proses pemanfaatan sumberdaya manusia dan sumber sumber lainnya secara efektif dan efisien untuk mencapai suatu tujuan tertentu (Malayu S.P Hasibuan: 1990).

Manajemen pendidikan adalah sebagai seni dan ilmu mengelola sumber daya pendidikan untuk mewujudkan suasana belajar dan proses pembelajaran agar peserta didik secara aktif mengembangkan potensi dirinya untuk memiliki kekuatan spiritual keagamaan, pengendalian diri, kepribadian, kecerdasan, akhlak mulia, serta ketrampilan yang diperlukan dirinya, masyarakat bangsa dan Negara. (Husaini Usman: 2010).

Dapat juga diartikan manajemen pendidikan juga merupakan rangkaian kegiatan bersama atau keseluruhan proses pengendalian usaha atas kerjasama. sekelompok orang dalam mencapai tujuan pendidikan yang telah ditetapkan secara berencana dan sistematis, yang diselenggarakan pada suatu lingkungan tertentu manajemen pendidikan pada hakekatnya menyangkut tujuan pendidikan, manusia ang melakukan kerjasama, proses sistemik dan sistematik,serta sumber-sumber yang didayagunakan. (E. Mulyasa: 2004)

Sebagai suatu tujuan yang telah ditetapkan tentunya manajemen mempunyai suatu langkah langkan yang sistemik dan sistematik dalam mencapai suatu tujuan yang ingin dicapai. Dalam arti yang lebih luas manajemen juga bisa disebut sebagai pengelolaan sumber-sumber guna mencapai suatu tujuan yang telah ditetapkan, karenanya manajemen ini memegang peranan yang sangat urgen dalam dunia pendidikan.

Tujuan manajemen pendidikan erat sekali dengan tujuan pendidikan secara umum, karena manajemen pendidikan pada hakekatnya merupakan alat untuk mencapai tujuan pendidikan secara optimal. Apabila dikaitkan dengan pengertian manajemen pendidikan pada hakekatnya merupakan alat mencapai tujuan.

Adapun tujuan pendidikan nasional yaitu untuk mengembangkannya potensi peserta didik agar menjadi manusia yang beriman dan bertaqwa kepada tuhan yang maha esa, berakhlak mulia, sehat, berilmu, cakap, kreatif, mandiri, dan menjadi warga Negara yang demokratis serta bertanggung jawab. Tujuan pokok memperlajari manajemen pendidikan adalah untuk memperolehcara, tehnik, metode yang sebaik-baiknya dilakukan, sehingga sumbersumber. Yang sangat terbatas seperti tenaga, dana, fasilitas, material maupun sepiritual guna mencapai tujuan pendidikan secara 
efektif dan efisien, (UU Sisdiknas No. 20 Tahun 200)

Dalam proses Manajemen terlibat fungsi-fungsi pokok yang diseorang manajer/ pemimpin, yaitu perencanaan (planning), pengorganisasian (organizing), pemimpinan (leading), dan pengawawan (controlling). (Nanang Fattah: 199)

\section{a. Perencanaan (planning)}

Dengan demikian perencanaan pendidikan adalah keputusan yang diambil untuk melakukan tindakan selama waktu tertentu (sesuai dengan jangka waktu perencanaan) agar penyelenggaraan sistem pendidikan menjadi lebih efektif dan efisien, serta menghasilkan lulusan yang lebih bermutu, dan relevan dengan kebutuhan pembangunan.

\section{b. Perngorganisasian (organizing)}

Untuk merancang organisasi perlu memperhatikan empat prinsip yaitu, koordinasi, scalar, fungsional dan staff. Pengorganisasian menurut handoko (2003) adalah:

1) penentuan daya dankegiatan yang dibutuhkan untuk mencapai tujuan organisasi;

2) proses perencanaan dan pengembagan suatu organisasi yang akan dapat membawahal-hal tersebut kearah tujuan;

3) penugasan tanggung jawab tertentu;

4) pendelegasian wewenang yang diperlukan kepada individu-individu untuk melaksanakan tugas-tugasnya. Ditambahkan pula oleh handoko pengorganisasian ialah pengaturan kerja bersama sumber daya keuangan, fisik, dan manusia dalam organisasi. Pengorganisasian merupakan penyusunan struktur organisasi yang sesuai dengan tujuan organisasi, sumber daya yang dimilikinya, dan lingkungan yang melingkupinya

Meskipun para ahli Manajemen memberikan definisi berbeda-beda tentang organisasi, namun intisarinya sama yaitu bahwa organisasi merupakan proses kerja sama dua orang atau lebih untuk mencapai tujuan organisasi Secara efektif termasuk organisasi pendidikan. Sedangkan unsur-unsur dasar yang membentuk suatu organisasi adalah

1. Adanya tujuan bersama yang telah ditetapkan

2. Adanya dua orang atau lebih/perserikatan masyarakat

3. Adanya pembagian tugas-tugas yang diatur dengan hak, kewajiban dan tanggung jawab.

4. Ada kehendak untuk bekerjasama dalam mencapai tujuan secara individu tujuan tidak dapat dicapai (Muhammad Bukori, Dkk: 2005)

\section{c. Penggerakan (actuating)}

Fungsi actuating merupakan bagian dari proses kelompok atau organisasi yang tidak dapat dipisahkan. Adapun istilah yang dapat dikelompokkan ke dalam fungsi ini adalah directing commanding, leading dan coordinating. (Jawahir Tanthowi: 1983)

Bimbingan menurut Hadari Nawawi, berarti memelihara, menjaga dan memajukan 
organisasi melalui setiap personal, baik secara struktural maupun fungsional, agar setiap kegiatannya tidak terlepas dari usaha mencapai tujuan. Dalam realitasnya, kegiatan bimbingan dapat berbentuk sebagai berikut:

a. Memberikan dan menjelaskan perintah

b. Memberikan petunjuk melaksanakan kegiatan

c. Memberikan kesempatan meningkatkan pengetahuan, keterampilan/kecakapan dan keahlian agar lebih efektif dalam melaksanakan berbagai kegiatan organisasi

d. Memberikan kesempatan ikut serta menyumbangkan tenaga dna fikiran untuk memajukan organisasi berdasarkan inisiatif dan kreativitas masing-masing

e. Memberikan koreksi agar setiap personal melakukan tugas-tugasnya secara efisien. (Hadari Nawawi: 1983)

\section{d. Pengawasan (controlling)}

Pengawasan merupakan aktivitas yang mengusahakan agar pekerjaan dapat terlaksana sesuai dengan rencana atau tujuan yang telah ditetapkan. Dengan kata lain pengawasan adalah mengadakan penilaian. Sekaligus koreksi sehingga apa yang telah direncanakan dapat terlaksana dengan benar. (Nanang Fattah: 1996)

Definisi lain tentang pengertian Kepala Madrasah dikemukakan pula dalam buku kendali mutu pendidikan agama Islam, yang menyatakan bahwa Kepala Madrasah adalah: "orang yang bertugas sebagai pemegang polisi umum dalam menentukan kebijakan di lingkungan Sekolah". (Departemen Agama RI, Kendali Mutu pendidikan Agama Islam: 2001)

Di samping sebagai seorang pemimpin Kepala Madrasah juga merupakan seorang bawahan yang harus mempertanggung jawabkan hasil yang dipimpinya kepada orang atau lembaga yang menunjuknya. Hal ini sabagaimana yang ditegaskan oleh $\mathrm{M}$. Ngalim Purwanto bahwa Kepala Madrasah adalah seseorang yang bertanggung jawab kepada atasannya terhadap tugas yang telah dipikulkan kepadanya pada lingkungan lembaga pendidikan". (M. Ngalim Purwanto: 1984)

\section{METODE PENELITIAN}

Jenis Penelitian ini adalah kualitatif, Penelitian kualitatif adalah jenis penelitian yang menghasilkan penemuan penemuan yang tidak dapat dicapai dengan menggunakan prosedur prosedur statistik atau dengan cara kuantifikasi lainnya. Melalui penelitian kualitatif peneliti dapat mengenali subjek dan merasakan apa yang mereka alami dalam kehidupan sehari-hari. Menurut definisi ini penelitian kualitatif menghasilkan data deskriptif sehingga merupakan rinci dari suatu fenomena yang diteliti. (Basrowi Sudikin: 2002)

Dalam mengumpulkan data yang dibutuhkan, penulis menggunakan teknik pengumpulan data sebagai berikut: 


\section{Observasi}

Observasi adalah mengadakan pengamatan secara langsung terhadap permasalahan yang dibahas. Observasi sangat diperlukan dalam pelaksanaan penelitian, karena melalui observasi peneliti akan mendapat gambaran lebih jelas dan konkrit tentang permasalahan yang dibahas. Dalam melakukan observasi, "keberadaan peneliti sebaiknya tidak diketahui oleh orang-orang yang diobservasi sehingga data yang diperoleh valid". (Winarno Surakhmad: 2001)

\section{Wawancara}

Wawancara yaitu mengadakan komunikasi secara langsung dengan sumber data penelitian untuk mendapatkan data yang dibutuhkan. Wawancara dilakukan terutama dengan kepala madrasah sebagai sumber data primer berkaitan dengan kepemimpinan dan manajemen Kepala Madrasah berpresatsi tingkat nasional di MTsN Sungayang Kabupaten Tanah Datar. Tujuan wawancara adalah untuk lebih memperkuat data yang diperoleh dari observasi.

\section{Studi dokumentasi}

Studi dokumentasi adalah cara pengumpulan data yang digunakan dalam metodologi penelitian sosial untuk menelusuri data historis. (M. Burhan Bungin: 2008) Studi dokumentasi juga dapat diartikan dengan analisis terhadap dokumen berupa catatan peristiwa yang sudah berlaku, baik yang berbentuk tulisan, gambar, atau karya-karya monumental dari seseorang atau lembaga. (Sugiyono: 2005)

Dalam menjabarkan data yang diperoleh penulis menggunakan metode deskriptif, yaitu menggambarkan fenomena atau peristiwa yang terjadi di lapangan sesuai dengan batasan masalah yang ditetapkan. Hal ini sesuai dengan ungkapan Suharsimi Arikunto yang menyatakan bahwa penelitian lapangan dapat dilakukan dengan menggunakan metode deskriptif yaitu menjabarkan keadaan di lapangan sesuai dengan kenyataan yang terjadi, sesuai dengan apa yang dijadikan objek penelitian. (Suharsimi Arikunto:1993).

Selanjutnya Winarno Surakhmad juga menegaskan bahwa pada umumnya penelitian yang menggunakan metode deskriptif merupakan penelitian yang tidak memerlukan langkah-langkah perumusan hipotesis, karena tujuannya adalah untuk menggambarkan keadaan atau fenomena yang terjadi di lapangan. (Winarno Surakhmad: 2001).

Uji keabsahan data dalam penelitian ini adalah meliputi: (Sugiyono: 2005)

\section{Uji Kredibilitas}

Pengujian kredibilitas data dapat dilakukan dengan cara perpanjangan pengamatan, peningkatan ketekunan dalam penelitian, triangulasi, diskusi dengan teman sejawat, analisis kasus negatif, dan member check. Validitas dan Reliabilitas Penelitian kualitatif.

Perpanjangan pengamatan artinya peneliti kembali ke lapangan, melakukan pengamatan, melakukan wawancara dengan 
sumber data, baik yang pernah ditemui maupun yang baru ditemui. Dengan perpanjangan pengamatan ini, hubungan peneliti dengan narasumber akan semakin terbentuk dan semakin akrab, semakin terbuka, saling mempercayai sehingga tidak ada informasi yang disembunyikan lagi.

Triangulasi dalam pengujian kredibilitas ini diartikan sebagai pengecekan data dari berbagai sumber dengan berbagai cara dan berbagai waktu. Dengan demikian, triangulasi terdiri atas triangulasi sumber, triangulasi teknik pengumpulan data, dan waktu. Triangulasi sumber dilakukan dengan cara mengecek data yang diperoleh melalui beberapa sumber. Data yang diperoleh dari beberapa sumber tersebut dideskripsikan, dikategorikan, dan akhirnya diminta kesepakatan (member check) untuk mendapatkan kesimpulan. Triangulasi teknik dilakukan dengan cara mengecek data pada sumber yang sama dengan teknik yang berbeda. Triangulasi waktu berkaitan dengan keefektifan waktu. Data yang dikumpulkan dengan teknik wawancara di pagi hari pada saat narasumber masih segar dan belum banyak masalah akan memberikan data yang valid sehingga lebih kredibel.

\section{Pengujian Transferability}

Transferability merupakan validitas eksternal dalam penelitian kualitatif. Validitas eksternal menunjukkan derajat ketepatan atau dapat diterapkannya hasil penelitian, agar orang lain dapat memahami hasil penelitian kualitatif sehingga ada kemungkinan untuk menerapkan hasil penelitian tersebut, peneliti dalam membuat laporannya harus memberikan uraian yang rinci, jelas, sistematis, dan dapat dipercaya. Dengan demikian, pembaca menjadi jelas dalam memahami hasil penelitian tersebut sehingga ia dapat memutuskan dapat atau tidaknya mengaplikasikan hasil penelitian tersebut di tempat lain.

\section{Pengujian Dependability}

Dependability disebut juga dengan reliabilitas. Penelitian yang reliabel adalah apabila orang lain dapat mengulangi/ mereplikasi proses penelitian tersebut. Dalam penelitian kualitatif, uji dependability ditempuh dengan cara melakukan audit terhadap keseluruhan proses penelitian. Audit dilakukan oleh auditor yang independen atau pembimbing.

\section{Pengujian Conformability}

Pengujian conformability dalam penelitian kualitatif disebut juga objektivitas penelitian. Penelitian dikatakan objektif jika hasil penelitian telah disepakati banyak orang. Menguji conformability berarti menguji hasil penelitian, dikaitkan dengan proses yang dilakukan. Bila hasil penelitian merupakan fungsi dari proses penelitian yang dilakukan, dapat dikatakan bahwa penelitian tersebut telah memenuhi standar conformability. Dalam penelitian jangan sampai proses tidak ada, tetapi hasilnya ada. 


\section{HASIL PENELITIAN}

Dari beberapa program kegiatan yang dibuat seperti: Muhadaroh, Shalat Dhuha, dan Shalat Dzuhur berjamaah, MOS, Pembuatan Mading, Pramuka, Perlombaan seni, olahraga, kegiatan social Menciptakan istilah-istilah yang sifatnya mendidik. Termasuk juga upacara bendera. Dalam pemantauan peneliti semua berjalan dengan baik, Tetapi pada program lain dapat peneliti amati sendiri seperti, muhadaroh di Madrasah, shalat dhuha dan shalat dzuhur berjamaah, pembuatan mading, Pramuka dan upacara bendera. Hal ini menunjukkan adanya antusias yang tinggi dari siswa dan dilakukan sesuai dengan jadwal yang ada, walaupun kekurangan-kekurangan seperti adanya siswa yang sulit diatur dan kualitas mading yang belum sempurna serta adanya siswa yang terlambat pada pelaksanaan upacara masih perlu mendapat pembinaan dari guru Pembina pada setia kegiatan.

Pelaksanaan shalat dhuha dan dzuhur berjamaah dilakukan setiap hari dan pembenahan mading $2 \mathrm{X}$ sebulan, muhadaroh $\mathrm{Hal}$ ini mampu memberikan kontribusi yang positif dalam meningkatkan mutu madrasah. Karena dari kegiatan ini mampu melahirkan karakter pribadi siswa ketaqwaan kepada Allah, keberanian berbicara di depan umum (Jamaah) disiplin, jujur, serta memberikan perubahan pada sikap dan tingkah laku siswa.

Guru pembina pada setiap kegiatan di MTsN Sungayang selalu bekerja ekstra untuk memberdayakan program-program dalam menjalankan programnya. Karena guru pembina merupakan tempat konsultasi bagi siswa. Maka dalam pengamatan peneliti, guru pembina setiap kegiatan di MTsN Sungayang selalu menjalin komunikasi intensif dengan Kepala Madrasah dan mendampingi siswa dalam setiap kegiatannya sekaligus memberikan masukan-masukan serta motivasi untuk penyempurnaan kegiatan.

Dalam meningkatkan mutu madrasah melalui kegiatan ini, selalu mengacu pada AlQur'an dan Hadist. karena sebagai Madrasah madrasah, pihak Madrasah beranggapan bahwa pemahaman terhadap nilai-nilai Al-Qur'an dan hadist Rasulullah.SAW merupakan hal pokok dalam meningkatkan mutu madrasah disamping UU pendidikan No. 20 tahun 2003.

Setiap pelaksanaan kegiatan dalam meningkatkan mutu madrasah, MTsN Sungayang selalu memberikan bimbingan, dan bimbingan berasal dari Kementerian Agama untuk pimpinan dan secara berjenjang bimbingan itu diberikan oleh pimpinan kepada wakil dan Pembina Kegiatan.

\section{Muhadaroh Pagi}

Kegiatan ini dilakukan saat sebelum pembelajaran dimulai. Setiap siswa memiliki kesempatan untuk menjadi pemimpin bagi siswa-siswa lainnya untuk membaca ikrar bersama. Selain itu, mereka memiliki kesempatan yang sama untuk menjadi pembicara dihadapan siswa-siswa lainnya dan guru 
dalam menyampaikan pendapat tentang berbagai hal, terutama yang berkaitan dengan nilai-nilai keislaman sehingga mampu melahirkan jiwa kepemimpinan dan percaya diri.

\section{Membuat Pengistilahan Kosa Kata} yang Mendidik

Menurut Rosnelly, selaku guru MTsN Sungayang,"Di bawah kepemimpinannya, dalam meningkatkan kualitas di madrasah, Kepala MTsN Sungayang berusaha mencari terobasan-terobasan baru, seperti membuat istilah-istilah baru dalam menerapkan kegiatan, adapun bentuknya adalah SAHARA TAMA (Setiap Hari Dhuha Bersama), S3 PALA (Satu Sampah Satu Pahala) dan SALJU SEMPONA (Salam Jumpa Senyum Pesona). Disamping itu Kepala MTsN Sungayang juga membuat kantin Ilmu, guna untuk menciptakan lingkungan yang gemar membahas masalah dalam keilmuan.

\section{Sholat Dzuhur Berjamaah, dzikir dan Doa, Sholat Dhuha}

Pembiasaan sholat berjamaah ini diharapkan dapat memupuk dan mengembangkan sikap mengutamakan kebersamaan dalam melakukan suatu kebajikan serta merupakan salah satu bentuk kegiatan pembiasaan dalam membentuk karakter siswa,hal ini dilaksanakan oleh seluruh siswa dan majlis guru MTsN Sungayang. Pada kegiatan ini setiap siswa juga memperoleh kesempatan untuk memimpin dzikir dan doa bagi siswa lainnya hal ini juga dimaksudkan untuk untuk membangun nilai-nilai Ketaqwaan dan kedisiplinan siswa dalam beribadah.

\section{Kegiatan Sosial}

Kegiatan ini rutin dilakukan dua tahun sekali. Tempat yang akan menjadi lokasi kegiatan sosial ditentukan berdasarkan tingkat kebutuhan daerah/tempat tersebut. Untuk memperoleh dukungan dana bagi kegiatan ini, maka sejak tahun 2008, siswa dan guru menyelenggarakan kegiatan penggalangan dana, berupa pentas seni peduli sosial, atau sejenisnya Hal ini dilakukan untuk memotivasi siswa dan guru agar tidak terjebak pada perilaku "tangan dibawah", meski untuk sebuah kegiatan sosial.

\section{Pembuatan Mading}

Pembuatan mading ini dilaksanakan 1 x 15 hari yang dikoordinir oleh para wali kelas, di mana para siswa mempunyai kreatifitas untuk menampilkan karya-karyanya serta menyampaikan beberapa aspirasi melalui mading ini,sehingga dengan demikian akan mampu menumbuhkan kecintaan siswa terhadap dunia jurnalistik serta mampu melahirkan karakter saling menghargai terhadap hasil karya orang lain serta merasakn kebebasan untuk berkreasi melalui majalah dinding tersebut. 


\section{UKS (Usaha Kesehatan Madrasah)}

Kegiatan ini diawali dari memperkenalkan teknik-teknik Pertolongan pertama pada kecelakaan kepada siswa serta bagaimana siswa mampu memberikan pelayanan kepada teman-temannya jika ada mereka yang sakit diMadrasah.Dalam pemantauan peneliti kegiatan UKS berjalan dengan baik dengan harapan siswa dapat menerapkan gaya hidup sehat serta mempunyai rasa kepedulian sosial yang tinggi kepada orang lain.

\section{Kegiatan Perlombaan}

Untuk menanamkan jiwa kompetitif serta memupuk rasa sportifitas pada siswa juga memprogramkan beberapa agenda perlombaan,biasanya dilaksanakan pada waktu Class Meeting setelah ujian semester,termasuk juga pelaksanaan lomba kebersihan lokal untuk memicu semangat siswa agar selalu memperhatikan kebersihan lokalnya serta memiliki tanggung jawab terhadap lokal tersebut.

Peran guru pembina dan guru-guru lain dalam mengevaluasi program-program yang dibuat oleh Kepala Madrasah sangat penting sekali. Karena dari pelaksanaan kegiatan tentu akan ditemukan kendalakendala. Seperti disiplin anak, motivasi menjalankan program kejujuran ini. Semua perlu bimbingan dan arahan dari pembina dan majlis guru. Sehingga dari kerjasama yang baik yang ditunjukkan oleh majlis guru melalui program PA (pembimbing akademik) yang ditetapkan oleh Kepala Madrasah dapat disinergikan dengan program yang dibuat untuk kualitas madrasah.

Kepala Madrasah sendiri dalam menjalankan roda organisasi melakukan rapat-rapat minimal $1 \mathrm{X}$ sebulan pada ruangan Kepala Madrasah yang disediakan oleh Madrasah. Dan di dalam rapat tersebut selalu mengevaluasi kegiatan-kegiatan yang dijalankan dan akan dilaksanakan di bawah bimbingan guru pembina. Karena pearn guru pembina sangat diharapkan ketika mereka menemukan masalah dalam menjalan program.

Setiap kegiatan memang memberikan pengaruh yang positif terhadap karakter siswa. Karena dari setiap kegiatan, selalu diberikan target perubahan kepda siswa. Dan hal itu akan terlihat diwaktu proses siswa dengan sesama siswa, siswa dengan guru, dan juga siswa dengan orang tua dan masyarakat. Di mana siswa mampu melihat karakter-karakter yang baik dalam proses pergaulannya sehari-hari di lingkungan Madrasah dan masyarakat. Serta perubahan karakter juga berpengaruh terhadap cara belajar anak. Karena jika anak sudah mempunyai karakter keimanan, kejujuran dan tanggung jawab, maka kesadaran anak untuk belajar dan mengikuti proses pembelajran semakin menguat agar mencapai prestasi yang baik, sebagaimana berikut. 


\section{PENUTUP}

\section{Kesimpulan}

a. Kepemimpinan dan manajemen Kepala Madrasah berprestasi tingkat nasional dalam membuat perencanaan di MTsN Sungayang Kabupaten Tanah Datar, yaitu dengan merencanakan program, Pelaksanaan muhadaroh di Madrasah, Membuat pengistilahan kosa kata yang mendidik, Pembiasaan shalat dhuha dan dzuhur berjamaah, Penilaian kebersihan lokal, Pembuatan mading Madrasah, Usaha Kesehatan Madrasah (UKS), Kegiatan perlombaan Olah Raga dan Seni, Kegiatan sosial dalam bentuk takziyah, menjenguk yang sakit, pengumpulan dana social, Pelaksanaan upacara bendera setiap hari senin dan Menciptakan istilahistilah yang sifatnya mendidik

b. Kepemimpinan dan manajemen Kepala Madrasah dalam membuat pengorganisasian di MTsN Sungayang Kabupaten Tanah Datar yaitu ntuk meningkatkan kualitas madrasah maka, Kepala Madrasah MTsN Sungayang membuat pengorganisasian yang meliputi organisasi kepemimpinan dan penanggung jawab setiap kegiatan.

c. Kepemimpinan dan manajemen Kepala Madrasah dalam pelaksanaan di MTsN Sungayang Kabupaten Tanah Datar, yaitu hampir semua kegiatan yang direncakan dapat terlaksana dengan baik, walaupun terdapat kendala-kendalannya, dan itu semua dapat teratasi dengan efektif. d. Kepemimpinan dan manajemen Kepala Madrasah dalam membuat pengawasan di MTsN Sungayang Kabupaten Tanah Datar, yaitu dengan pengawasan yang dilakukan untuk melihat kelemahankelemahan serta program yang telah dilaksanakan guna menyempurkan pelaksanaan program untuk membentuk katrakter siswa. Evaluasi dilakukan dalam pemberian laporan yang dilakukan dan dibahas secara bersama-sama.

\section{Saran}

a. Diharapkan kepada Kepala Madrasah bersama-sama warga Madrasah selalu menyusun memantau untuk kualitas madrasah dan memberikan masukan yang konstruktif untuk perkembangan madrasah selanjutnya.

b. Diharapkan kepada komite Madrasah dan tokoh-tokoh masyarakat selalu melibatkan diri dalam memberikan masukan-masukan untuk meningkatkan kualitas madrasah agar terwujudnya tujuan pendidikan.

c. Diharapkan kepada pengawas Madrasah secara berkala membimbing Kepala Madrasah untuk melaksanakan pengelolaan dan bimbingan secara kontiniutas Kepala Madrasah, untuk meningkatkan kualitas madrasah.

d. Diharapkan kepada Dinas Pendidikan dan Kementerian Agama untuk dapat meningkatkan kompetensi dan pengetahuan Kepala Madrasah, komite 
Madrasah, pendidik (guru) dan tata usaha Madrasah dalam meningkatkan mutu Madrasah.

\section{KEPUSTAKAAN ACUAN}

Departemen Agama RI, (2001). Kendali Mutu pendidikan Agama Islam, Cet. ke-1 (Jakarta: Depag RI.

Depdiknas, (2000). Panduan Manajemen Sekolah. (Departemen Pendidikan Nasional Direktorat.

E. Mulyasa, (2004). Manajemen Berbasis Sekolah; Konsep, Strategi dan Implimentasi, (Bandung: Remaja Rosda Karya.

----, (2005) Menjadi Kepala Madrasah Profesional, Bandung: PT. Remajda Rosda Karya.

Hasibuan, SP. Malayu. (2001). Manajemen Sumber Daya Manusia, Jakarta: Bumi Aksara.

Husaini Usman, (2010). Manajemen: Teori, Praktik dan Riset Pendidikan (Jakarta: Bumi Aksara.

M. Ngalim Purwanto, (1991). Administrasi dan Supervisi Pendidikan, Bandung: PT. Remaja Rosdakarya
Made Pidarta, (1986). Pemikiran Tentang Supervisi Pendidikan, Surabaya: Sarana Press.

Muhammad Bukori, Dkk, (2005). AzasAzas Manajemen, Yogyakarta: Aditya Media.

N.A.Amentambun, (1981). Supervisi Pendidikan Pendidikan Madrasah dan Guru, Bandung: Armico.

Ngalim Purwanto, dkk, (1984). Adminitrasi Pendidikan, Jakarta: Mutiara.

Sondang P. Siagian, (1997). Sistem Informasi untuk Mengambil Keputusan, (Jakarta: Gunung Agung.

Sugiyono, (2005). Memahami Penelitian Kualitatif, Bandung: ALFABETA.

Suharsimi Arikunto, (1993). Metode Penelitian Suatu Pendekatan Praktek, (Jakarta: Rineka Cipta.

UU Sisdiknas No. 20 Tahun 2003

Winarno Surakhmad, (2001). Penelitian Pendidikan, Jakarta: Rineka Cipta, Cet. Ke-6 